\title{
THE STATE OF DEVELOPMENT OF EQUESTRIAN TOURISM IN THE LUBLIN REGION IN THE CONTEXT OF ENVIRONMENTAL CONDITIONS
}

\author{
Equestrian tourism in the Lublin Region
}

\author{
TERESA BRZEZIŃSKA-WÓJCIK, MONIKA BARANOWSKA \\ Maria Curie-Skłodowska University in Lublin, Faculty of Earth Sciences and Spatial Management, \\ Department of Regional Geography and Tourism
}

\begin{abstract}
Mailing address: Teresa Brzezińska-Wójcik, Maria Curie-Skłodowska University in Lublin, Department of Regional Geography and Tourism, 2cd Kraśnicka Avenue, 20-718 Lublin, tel.: +48 8153768 51, fax: + 488153768 62, e-mail: tbrzezin@poczta.umcs.lublin.pl
\end{abstract}

\begin{abstract}
Introduction. In recent years spending free time in the Lublin Region has been more frequently related to equestrian tourism based on the infrastructure of the existing centres. Papers published so far focus mainly on a detailed description of features of horses used for equestrian tourism. Few papers have analysed offers and issues related to the promotion of this form of tourism. There is no paper discussing the spatial distribution of equestrian tourism centres, or analysing their offer at the regional scale. In response to this, a study was undertaken with special consideration of the features of the natural environment. Material and methods. In the period from October 2010 to April 2011, secondary information (statistics, registers, scientific papers) was analysed and primary material (field inventory, diagnostic interviews and an opinion poll) on the state of equestrian tourism in the Lublin Region was collected. Results. The analysis of the spatial distribution of 61 equestrian tourism centres subject to the inventory reveals that the highest number of centres function in the Zamość and Biała Podlaska poviats. The comparison of offers in the scope of equestrian tourism in the Lublin Region shows that the basic offer of the region includes four kinds of services: horse riding, sleigh riding, chaise riding and horse riding courses. The highest number of horse treks is offered by centres in the Biała Podlaska poviat. Conclusions. In view of the data obtained, an asset in the scope of the development of equestrian tourism is the structure of offers directed at tourists and the infrastructure that already exists. Moreover, the development of this form of tourism is favoured by the features of the natural environment; the majority of trails and centres are located in environmentally valuable areas. Particularly the landscape, the filtrating-detoxicating properties of plant assemblages, their bioclimate and aesthetic value should contribute to the development of a complex offer (appropriate promotional package) of equestrian tourism in the Lublin Region.
\end{abstract}

Key words: equestrian tourism, environment, Lublin Region

\section{Introduction}

Equestrian tourism is an increasingly popular form of active recreation [1], enabling contact with nature and cultural objects. Moreover, horse riding is good for the health and physical condition [2]. Equestrian tourism, as a form of broadly understood active tourism and a form of qualified tourism, is practised in free time for the purpose of exploring the country or region [3]. It is practised individually or/and in an organised form, mainly horse riding holidays and weekends, youth holiday camps and horse treks [4]. Equestrian tourism is also practised by a large group of people who only visit stud farms and horse breeding centres, as well as auctions, passively participate in equestrian events (tournaments, rodeos, shows), take chaise, cart, or sleigh rides and participate in feeding and cleaning of horses [5]. The term equestrian tourism often refers to horsebased tourism, or horse-riding tourism involving recreational horse riding in equestrian centres or in the field, outside the place of residence [6]. A detailed comparison of the meaning of the terms horse-based tourism, horse-riding tourism and horseriding recreation was performed by M. Jarzębowska, A. Kowal- czyk, S. Kulczyk, A. Kurkowska, W. Lewandowski (2010). One of the latest disciplines related to equestrian tourism is hippotherapy [7]. The scope of hippotherapy activities is much wider in Poland than in other countries such as Germany and concerns any therapeutic activities conducted with the participation of a horse, including physiotherapy on horseback, psychopedagogical horse riding and therapy with a horse [8].

The background and history of equestrian tourism in Poland was presented by S. Kubacki et al. (2006 and literature cited therein), M. Adamowicz and I. Świtek (2009), as well as M. Józefczyk (2010), drawing attention to aspects of the development of this form of tourism such as the role of the cavalry $\left(16^{\text {th }}\right.$ century), Lisowczycy (17 ${ }^{\text {th }}$ century), long-distance sports treks $\left(20^{\text {th }}\right.$ century) or first horse treks in mountain conditions [2, 9, 10]. The popularisation and development of trails and equestrian tourism centres in Poland since the 1990's have been the responsibility of the Polish Equestrian Federation [11], commissions affiliated by PTTK [12], the State Forests National Forests Holding [13], gmina associations, other non-governmental organisations, self-governmental entities and private individuals [9]. For the purpose of popularising horseback riding recreation, 
a number of equestrian tourism trails have been established in various regions of Poland $[14,12,3,15]$. Three trails were also established in the Lublin Region: Polesie Horse Trail [16, 17], Uhlan Horse Trail and Roztocze Horse Trail [18]. In recent years, the number of agrotourist centres has also increased, offering various attractions, including those satisfying needs in the scope of equestrian tourism $[4,19]$. Owners of the centres treat the offer related to horses as an asset attracting tourists [20,21]. The development of equestrian tourism is seen by many as a chance for the promotion of East Poland [22, 23].

The Lublin Region (Lublin Voivodship) has rich traditions and achievements in horse breeding and horse riding. The core of the development of equestrian tourism is the Janów Podlaski Stud Farm, functioning for approximately 200 years [24] and the Stallion Depot Białka near Krasnystaw, functioning since 1930 [14]. The Feliński Pony breed with the appearance and profile of a pure-bred horse was reared under the supervision of Prof. E. Sasimowski at the University of Life Sciences (former Academy of Agriculture) in Lublin. Specialisation "Horse breeding and riding" also functions at the university [19] and from the academic year 2012/2013, also a new major "Hippology and horse riding" [25]. Moreover, in Zwierzyniec and Florianka in the Roztocze National Park, the reserve and stud farm breeding of the Konik Polski, a direct descendant of the wild Tarpan, was restored. A haven of the Konik Biłgorajski exists in the vicinity of Janów Lubelski [26]. A feature common to the Feliński Pony, Konik Polski and Konik Biłgorajski is their usefulness for equestrian and recreation tourism as well as for hippotherapy [27].

In the 1990's in the Lublin Region, a number of private stud farms were established, raising horses of various breeds: purebred arabians, pure-bred English, Małopolska and Wielkopolska horses, Hanoverians, Holsteins, Konik Polski and Hutsuls. Simultaneously, equestrian centres developed dynamically, offering horse riding courses as well as practising sports disciplines such as dressage, horse jumping, horse trials, combined driving and long-distance treks [26].

In recent years, spending free time in the Lublin Region has been more frequently related to equestrian tourism based on trails and centres offering services in the scope. Therefore, an inventory of trails/places/towns enabling participation in various types of this form of tourism is needed. Due to this, the present paper presents the quantitative and qualitative results of the inventory of centres and offers of equestrian tourism as well as the horse trails in the region. It also presents the spatial distribution of equestrian tourism centres in the Lublin Region in the context of features of the natural environment. Moreover, it discusses the issue of promotion of the environmental value of the Lublin Region in relation to the possibilities of practising equestrian tourism.

\section{Environmental features of the Lublin Region that are useful for equestrian tourism}

Good conditions for the development of equestrian tourism in the Lublin Region are determined by natural resources and particularly landscape and diverse vegetation. The landscape results from the geological structure and climatic conditions affecting land denivelations and the spatial distribution of surface waters. Diverse vegetation resources, depending on the species, have filtrating-detoxicating and healing properties, as well as aesthetic qualities. They also influence the landscape throughout the year. The visual attractiveness of the landscape is an important element of the recreational value of the region [28].

Based on the division of Poland into tourist regions, considering the physicogeographical division of Poland according to J. Kondracki and A. Richling (1994), the Lublin Region includes three subregions: Polesie (northern part), Kazimierz-Nałęczów and Roztocze (middle part) and Sandomierz (southern part)
[29]. The features and boundaries of the subregions refer to three landscape belts: lowlands in the north, uplands in the middle part and premontane depressions in the south [30, 31].

The northern lowland belt of the region includes the Mazowsze Lowland and West and South Polesie Lowlands. In the Mazowsze part, absolute heights vary from 160 to $200 \mathrm{~m}$ and denivelations do not exceed $30 \mathrm{~m}$. In the Polesie part, denivelations reach only $10 \mathrm{~m}$ and extensive peatland areas occur [32, 33]. In this part of the region, in the Łęczna-Włodawa Lakeland, 68 lakes with a surface area of more than 1 ha occur [34]. The area is distinguished by the lowest annual precipitation total in the Lublin Region (520-550 mm). The mean number of sunny days varies from 28 in the vicinity of Puławy to 48 in Radzyń Podlaski [35]. Among vegetation resources, carbonate peatlands and marshy coniferous forests (assemblages from class $O x y$ cocco-Sphagnatea, assemblage of Vaccino uliginosi-Pinetum), as well as less abundant pine-oak forests (Querco roboris-Pineetum) are typical [36, 37]. The bioclimate of carbonate peatlands and marshy coniferous forests is specific. On the one hand, high air humidity and high concentration of pollen of plants does not favour a prolonged stay in those assemblages. On the other hand, favourable conditions are provided by strong biotherapeutic effect of aerosols. As a consequence, the assemblages have a stimulating and antiseptic effect on the organism. Carbonate peatlands and marshy coniferous forests are unique in visual and aromatic terms, with predomination of dark brown shades with various shades of green and sometimes red and white. Such combinations of colours have a stimulating effect on people [37].

The middle part of the Lublin Region includes macroregions with typical upland relief, the Lublin and Wołyń Uplands, Roztocze and a small part of the Pobuże Basin [38]. They are distinguished by higher and more varied absolute heights. The macroregion located at the highest latitude is Roztocze, reaching more than $300 \mathrm{~m}$ a.s.l. In the macroregions of the Lublin Upland, Wołyń Upland and Pobuże Basin, areas of more than $200 \mathrm{~m}$ a.s.l. prevail. The upland belt includes outcrops of Upper Cretaceous siliceous-carbonate rocks, locally covered by deposits of loess on elevations and mineral-organic formations in depressions and valleys [31]. Within the range of loess patches, significant relative heights (from 30-40 to 100-120 m) and high sensitivity of the formations to the activity of water, result in the intensive development of gullies [30]. This landscape belt is drained by the Wieprz, Bug, San and Vistula Rivers [39]. The upland belt is distinguished by the highest precipitation total in the area analysed: $650-750 \mathrm{~mm}$ annually (Roztocze), but also by the highest mean number of sunny days; approximately 47 in Zamość [35]. Dry-ground forests (assemblages associated with Carpinion betuli), thermophilous oak forests (Potentillo albae-Quarcetum) and locally acidophilic oak and beech forests (assemblages from class Quercetea robolipetraeae and in association with Luzulo-Fagion) [36, 37] are typical plant associations. The filtrating-detoxicating properties of dry-ground forests and their bioclimate have a stimulating effect on the nervous system, stimulate activity and combat fatigue. The effect of the assemblages is universally positive, particularly in spring. In summer, factors limiting their touristic-recreational use include ticks and outbreaks of mosquitoes and gadflies. In aesthetic terms, dry-ground forests constitute an assemblage with contrasting colours: in spring; white, yellow and violet-blue colours predominate and in summer; light green and various shades of brown. Those combinations of colours have a relaxing and stimulating effect. Thermophilous oak forests are universally beneficial for health. High concentration of volatile organic substances occurring from early spring to mid-summer has an antiseptic and stimulating effect. In aesthetic terms, the assemblages are among the most beautiful in Poland, with predominating vivid green from early spring to late 
summer and cinnabar-red colours from late summer to late autumn [37].

The southern part of the region belongs to the macroregion of the Sandomierz Basin. It includes plain and plateau areas with denivelations of 10-40 m [40]. The plains with shallow and paludified depressions are mainly composed of sands [41, 40]. The plateaus are mainly composed of Miocene clays covered by Quaternary formations. This part of the Lublin Region belongs to the catchment area of the San River and is drained by the Tanew River and its tributaries [31, 40]. It is distinguished by high insolation. The mean values of the sums of incoming solar radiation and actual insolation are among the highest in comparison to other regions of Poland [35]. Pine forests are typical here (assemblages in association with Dicrano-Pinion) and locally, in river valleys, also alder forests and alder riverside carrs (assemblages of Ribo nigri-Alnetum and Circaeo-Alnetum) [36, 37]. In terms of filtrating-detoxicating properties, pine forests in particular have a healing effect on the respiratory system. In addition to the disinfecting properties, volatile substances have a toning effect on the nervous system. In aesthetic terms, pine forests are devoid of seasonal colour. Shades of light brown and grey-blue-green with dark green prevail. This combination of colours has a relaxing effect, similarly as the acoustic and aromatic stimuli, as well as the extensive view perspective providing the feeling of safety [37].

The study area, valuable in environmental terms, is subject to a number of forms of legal protection. Some of the areas/ objects have been adopted for tourism, among others two National Parks; the Polesie and Roztocze National Parks, 17 Landscape Parks and 17 areas of protected landscape, as well as some of 1600 nature monuments and 4 documentation sites [36].

The duration of the optimal period of using the summer landscape of the natural environment in particular landscape belts of the Lublin Region does not vary much. It is the shortest, from 130 to 140 days in the northern lowland belt. In the upland and premontane belts, it amounts to 140-150 days [42].

\section{Material and methods}

The first stage of the study on equestrian tourism in the Lublin Region was based on secondary information (promotional folders, tourist information brochures, official websites, programmes of tourist events, advertisements, scientific and popular science publications, cartographic data, data from registers). The second stage, based on primary information (freeform interview with a standardised list of required information, opinion poll) [43], involved research on the core issue of the paper. The field inventory and interviews were conducted from October 2010 to April 2011. They verified information obtained during the desk study and supplemented knowledge on resources determining the development of equestrian tourism in the Lublin Region. Comparative tables presenting the offers and the spatial distribution of equestrian tourism centres constituted the basis of the analysis of possibilities of development of equestrian tourism in the Lublin Region.

\section{Results}

According to the data collected during the field study, 61 centres providing services related to equestrian tourism function in the Lublin Region (Fig. 1). This constitutes only $5.5 \%$ of centres of the type in Poland [14]. The highest number of centres offering equestrian tourism services function in the Zamość - 10 (Roztocze) and Bielsko Biała poviats - 9 (Polesie). The lowest number with only 1 centre was recorded in the Opole and Parczew poviats (Fig. 2). No centres are located in the
Kraśnik, Lubartów and Łuków poviats and in the urban poviats of Biała Podlaska, Chełm and Zamość.

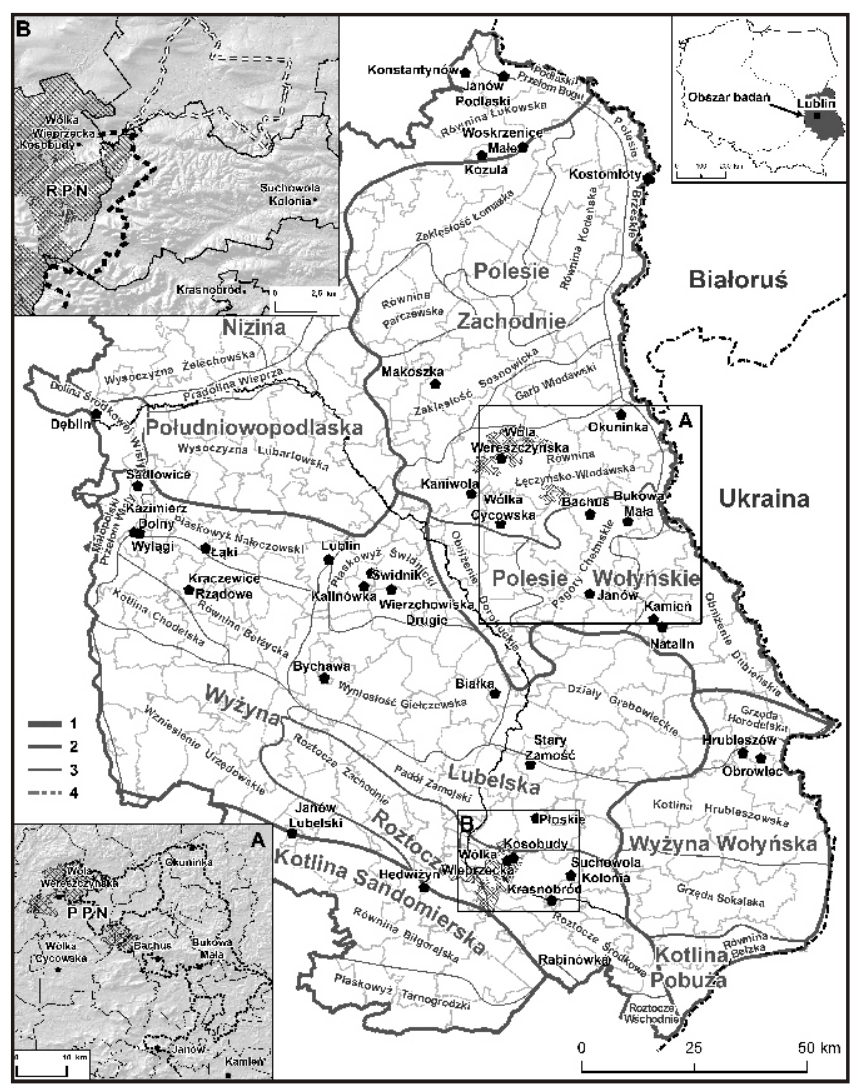

Figure 1. Spatial distribution of centres related to equestrian tourism in the Lublin Region in relation to physicogeographical boundaries of regions (following J. Kondracki and A. Richling 1994)

Course of horse trails: A - Polesie Horse Trail, B - Uhlan and Roztocze Horse Trails; boundaries of physicogeographical regions: 1 - subprovinces, 2 - macroregions, 3 - mesoregions; 4 - boundaries of gminas

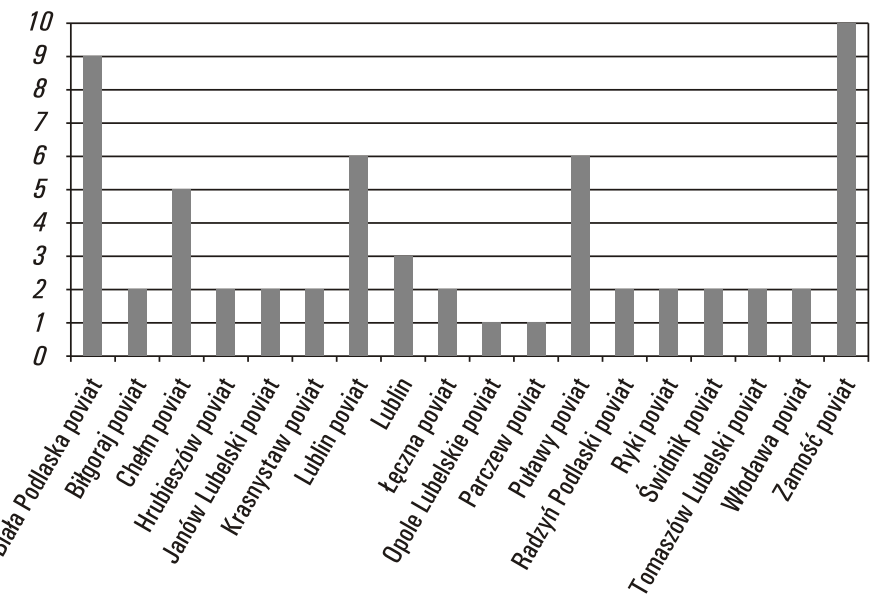

Figure 2. Number of centres providing services related to equestrian tourism, by poviat

Source: own elaboration based on: field inventory and interviews, as well as "Województwo Lubelskie Informator 2010"; www.lubelskie.pl, www.galopuje.pl, www.stadniny.pl, official websites of equestrian centres, official websites of cities and regions of the Lublin Region, interviews. 
The distribution of centres providing services related to equestrian tourism results from the following factors: 1) breeding traditions in the case of the Biała Podlaska poviat, 2) supplementing the offer of agrotourism centres with equestrian services - economic factor, and 3) environmental usefulness of the area for practising equestrian tourism. The areas mentioned are distinguished by unique landscape resulting from diversified land relief (Lublin Upland, Roztocze) and large areas of forests and lakes (Polesie).

A relatively high number of centres also function in the Lublin and Puławy poviats in the Lublin Upland. Their location is related to potential demand for the "new" type of services and the environmental attractiveness for tourists. In the Lublin poviat, good conditions for the development of this form of tourism result from the area's proximity to a large city (Lublin) and the surrounding large forest complexes (a so-called green belt around the city). The Puławy poviat is an area popular, among tourists due to the culture found in towns such as Kazimierz Dolny, Nałęczów and Puławy - the "touristic triangle". It is distinguished by exceptional beauty resulting from diverse land relief (loess gullies) and high forest cover.

\section{Offer of equestrian tourism centres in the Lublin Region}

The analysis of service offers of the centres directed at tourists reveals that horse riding is the most frequently offered service (more than $98 \%$ of the centres subject to the inventory; Fig. 3). More than $93 \%$ of the centres offer sleigh riding and the same percentage offer chaise riding. Almost all of the centres (92\%) also offer horse riding courses. Those four services constitute the basic offer of the Lublin Region in the scope of equestrian tourism.

In addition, almost $38 \%$ offer pensions for horses and $31 \%$ horse treks. More than 21\% of the centres offer hippotherapy services and $18 \%$ horse riding day camps and camps. Approximately $15 \%$ of the centres organise horse shows and approximately $10 \%$ also offer horse rental.

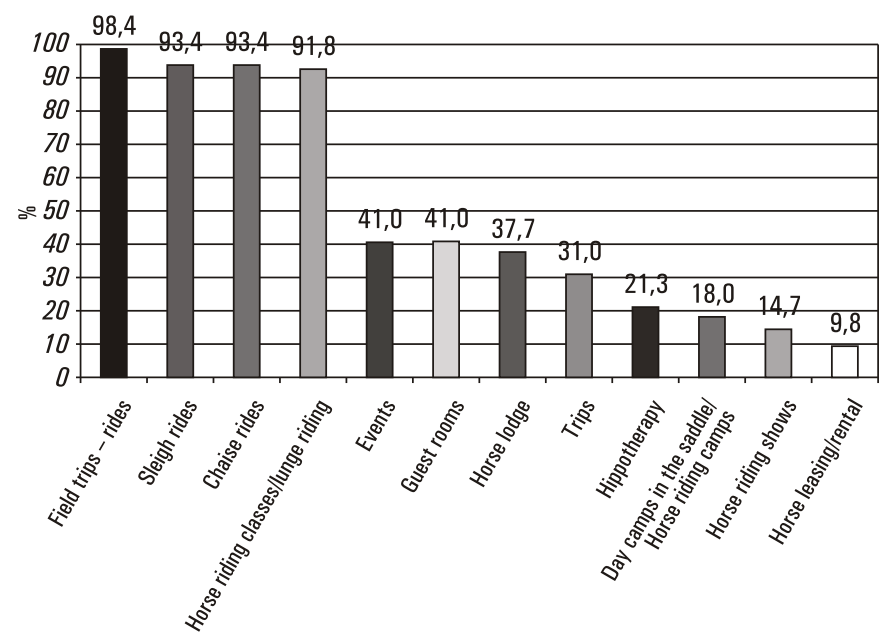

Figure 3. Services offered in equestrian tourism centres in the Lublin Region.

Source: own elaboration based on: field inventory and interviews, as well as "Województwo Lubelskie Informator 2010"; www.lubelskie.pl, www.galopuje.pl, www.stadniny.pl, official websites of equestrian centres, official websites of cities and regions of the Lublin Region, interviews.

Other services related to equestrian tourism offered by centres include breeding stallions, swimming with horses, horse training, auctions and tenders, sports training, horse jumping courses, preparation for sports tournaments and obtaining riding badges, or the innovative skiring. The data cited show a positive image of equestrian centres in the Lublin Region, offering a relatively wide scope of services.

In the scope of the basic services, $41 \%$ of centres subject to the inventory offer accommodation and the same percentage declares organisation of special, integration and family events (Fig. 3).

Horse riding, the most frequently provided service, is possible owing to equestrian tourism trails (Fig. 1). The total length of the three horse trails amounts to $355 \mathrm{~km}: 294 \mathrm{~km}$ of the Polesie Horse Trail, $34 \mathrm{~km}$ of the Uhlan Horse Trail and $27 \mathrm{~km}$ of the Roztocze Horse Trail.

The concept of the Polesie Horse Trail (Fig. 1A) was developed by members of the Regional Society of Gmina Sawin in cooperation with the equestrian centre "Żurawiejka" in Bukowa Mała in 2006. The trail runs through West Polesie and Polesie Wołyńskie (12 gminas of the Chełm and Włodawa poviats). The execution of the professional horse trail was done with the participation of self-governments of gminas of the Chełm and Włodawa poviats and the cities of Chełm and Włodawa, as well as the Polesie National Park, management of the Polesie Landscape Parks and the Chełm, Sobibór and Włodawa forest divisions. The undertaking covers an area of $1270 \mathrm{~km}^{2}$, with more than 130 thousand inhabitants. The trail runs through areas with varied land relief with numerous lakes and large forest complexes and enables visiting the most interesting places in the Polesie National Park, Chełm, Sobibór and Polesie Landscape Parks, as well as numerous nature reserves (Lake Orchowe, Magazyn, Żółwiowe Błota wetland, Lake Brudzieniec, Three Lakes, Małoziemce, Sereniawy, Bachus, Stawska Góra, Bagno Serebryskie wetland, Brzeźno and Roskosz). One of the most impressive fragments of the trail runs along the naturally meandering Bug River, unique at the European scale due to the nesting of a number of bird species. The attractiveness of the trail is also influenced by its location at the meeting point of various cultures, reflected in valuable relics of secular and sacred architecture and old traditions [17]. The degree of difficulty of the trail is described as easy and medium; the network of paths is adjusted to the needs and abilities of riders. An advantage of the trail is the multiple variants of the course of the trail. The trail has sandy and dirt roads. The infrastructure includes signposts, information boards, pastures, hitching posts, camping sites, tourist roofings, bonfire places, viewpoints and view towers located on the trail and in its vicinity, as well as stables and agrotourist farms.

Both the Uhlan and Roztocze Horse Trails (Fig. 1B) were designed in a manner enabling completing each of them within one day. They run though the middle part of Roztocze, called the Middle or Tomaszowskie Roztocze, the part of the Lublin Region that is most varied in terms of landscape. The Uhlan and Roztocze Horse Trails were established in 2007 and are pioneer horse trails in the Lublin Region, labelled by the Zamość Branch of PTTK.

The Uhlan Horse Trail has the shape of a loop. The starting and finishing point are located at the stud farm of Małopolski horses "Chutor Tarka" in Wólka Wieprzecka (Fig. 1B). The Roztocze Horse Trail also begins at the "Chutor Tarka" stud farm, but has a linear course and runs in the southern direction to the village of Senderki [9, 44]. While riding along both of the trails, one can observe picturesque hills, river valleys and extensive forest areas. Attractions located at the trails are nature (including the "Hubale" reserve with speckled ground squirrels and the Echo ponds, the haven of Konik Polski in the Roztocze National Park) and cultural sites. In the Roztocze National Park, trails for riding Konik Polski were established. Horse riding is also possible on the cycle path to Florianka, the landscape path in Florianka, the boundary trail between Florianka and the Park in the direction of Tereszpol and the "Tereszpolska" road along section 
207. A specific form of equestrian tourism, combined with environmental protection, is practised by the Roztocze Environmental Protection Horse Riding Guard in Florian. It is the only entity which can independently ride horses in the Roztocze National Park $[9,44]$. Both of the trails are assessed as of medium difficulty. They have dirt roads and locally asphalt roads. The infrastructure includes signposts and pastures.

A number of unlabelled (and usually lacking any infrastructure) horse trails and paths with a very local character, often running in the vicinity of equestrian centres, also function in the Lublin Region.

\section{Horse treks in the Lublin Region}

According to the data collected, horse treks in the Lublin Region are offered by 19 centres (31\% of all centres in the Lublin Region). Unfortunately, comparison of the phenomenon in the Lublin Region and Poland is impossible due to a lack of statistical records. In Poland in 2010, 248 horse treks were organised, with the participation of 4,692 persons, including 2,257 persons at school age (48.1\% of participants) [45].

The analysis of centres offering horse treks in the Lublin Region (Fig. 1) reveals that the highest number of centres of the type (3) function in the Biała Podlaska poviat, followed by two centres in the Łęczna, Puławy, Tomaszów Lubelski and Zamość poviats. Single centres function in the Chełm, Krasnystaw, Lublin, Parczew, Radzyń Podlaski, Ryki, Świdnik and Włodawa poviats.

Therefore, equestrian centres organise horse treks on trails mainly located in the area of Polesie along the Bug River and in Roztocze. Three centres in Polesie (The Equestrian Centre Żurawiejka, Agrotourist Farm Cyganówka and Renata Grabowska) organise treks along the trails of the Polesie Horse Trail and along trails located in the Polesie National Park and its buffer zone [17, 9, 46]. Two centres in Polesie (centre of M. Falkiewicz and Equestrian Centre Żurawiejka) organise treks in areas along the Bug River, in the Podlasie Bug River Gorge Landscape Park and the "Bug River Meanders" trek, respectively. In Roztocze, organisation of treks, based on, among others, the Uhlan and Roztocze Horse Trails, is declared by seven centres (Małopolski Horse Stud Farm TARKA, Stud Farm Rozalia in Wólka Wieprzecka, Stud Farm Pod Lasem in Dąbrowa Tomaszowska near Tomaszów Lubelski, Stud Farm Rogowe Kopce in Rabinówka near Tomaszów Lubelski, Stud Farm Zagroda Roztocze in Obsza, Makoń Andrzej Marynicz in Narol-Wieś and the EquestrianRecreation Centre Bretania in Nowa Wieś near Krasnobród) [9, 44].

Single centres advertise horse treks in the Lublin Upland. The Equestrian Club Arvena provides services in the scope on the Giełczewska Plateau in the Krzczonowski Landscape Park and Dwór w Wylągach; in the "Land of Loess Gullies" located in the gminas of Janowiec, Kazimierz Dolny, Puławy, Nałęczów, Opole Lubelskie, Poniatowa, Wąwolnica and Wojciechów [46, $47,48]$. One centre, namely the Equestrian Club Goniec in Ludwin, organises treks in the Łęczna-Włodawa Lakeland.

Some of the centres analysed (e.g. Stable Borysiuk) have a very general offer involving the organisation of treks in the Lublin Region and Podlasie. Five centres advertise horse treks without specification of details regarding the trails. Two centres (Sport and Recreation Centre Wiosenny Wiatr and EquestrianRecreation Centre Oxer) offer trails designed by themselves on their websites.

The offers of horse treks usually include accommodation and meals. Some centres also provide organisation of additional attractions. The duration of treks is varied: from 1-2 days to 3 days and more. All the stud farms and equestrian centres hold the Hubertus event every year around 3 November. It is a chase in celebration of St. Hubertus the patron saint of hunters, foresters and riders [18].

\section{Discussion}

According to the survey conducted by J. Janiszewska and J. Ignor (1998), recreation in agrotourist farms is preferred by $75 \%$ of the respondents and $65 \%$ of respondents emphasised that horses are the biggest attraction [3]. The study conducted in 2008 in southern Podlasie and Polesie in 25 selected agrotourist centres [19] reveals that 18 centres (72\% of accommodation providers) only offer accommodation and 7 (28\%) also offer riding services. It turns out that, in agrotourist farms exclusively offering accommodation, the mean annual use of accommodation places is low and amounts to only $8.8 \%$. In agrotourist farms additionally offering equestrian services, this value at the annual scale amounts to $30.8 \%$. The use of accommodation places here is 3.5 times higher. It is worth attention that in agrotourist farms not providing equestrian tourism services, the phenomenon of seasonality is very clearly observed, with the peak in the summer season. Meanwhile, in agrotourist farms offering equestrian tourism services, in addition to considerably higher use of accommodation places, the phenomenon of lower seasonality in tourist traffic is observed.

The studies cited suggest that supplementing the agrotourist offer with equestrian services would considerably increase the attractiveness of the centres, which would undoubtedly result in measurable economic benefits [49] and in a wider scope in the development of rural tourism in the Lublin Region. According to J. Janiszewska and J. Ignor (1998), different uses of horses can be perfectly adopted to the agrotourism activity and attract tourists [3]. This way, equestrian tourism can contribute to the revival of the local tourist traffic and fulfil an important function in increasing the competitiveness of the region. Also according to J. Herbert (2009), the society will more eagerly engage in horse riding, if the values of such a manner of spending free time are more frequently emphasised [15].

The Lublin Region with a documented environmental potential has a relative drawback, namely a small network of established and labelled horse trails and insufficiently prepared accompanying infrastructure. The existing trails are too local and under-managed in tourist terms. In order to accurately use the existing potential, the engagement of equestrian centres in the process of development of necessary tourist infrastructure is required. A very important element is cooperation of centres in designing horse trails. Each centre could design horse trails which then could be connected into horse trails running between the centres. This way, somewhat automatically, the trails could be equipped, at least partly, in the necessary tourist base (mainly stables, food for horses and often accommodation for tourists). The trails should be designed to be attractive not only for the narrow group of tourists proficient in horse riding, but also for those who started their adventure with horses relatively not long ago. The task can be executed for example by using subsidies from the structural funds of the European Union. A model example is the Łódź Horse Trail, analysed by B. Gosik and M. Piech (2012) [50].

The promotional tools applied by centres in the Lublin Region show that so far, the most popular form of promotion of centres are websites and sale of the offer through some of them. Meanwhile, an important promotional tool is the participation of the centres in tourist fares, exhibitions, workshops and presentations. A unified information (information centres and points equipped in digital devices) and navigation system (boards and billboards, direction signs, GPS devices) should also be developed.

For promotional purposes, also a folder with complex information on centres, trails and tourist attractions located on the trails is also worth developing. It should emphasise the very positive visual impact of the landscape, the filtrating-detoxicating properties of the plant assemblages, their bioclimate and 
the effect of their aesthetic value on the human organism. The folder will enable the tourist to select the trail that is the most interesting for them. Moreover, this form of tourism should be advertised through the popularisation of the local horse breeds (Hutsuls, Konik Polski, Małopolska horses, pure-bred arabians, Sokólski horses and Feliński Ponies). The use of the local horse breeds [14] can become a specific regional speciality.

\section{Conclusions}

The Lublin Region has a large potential, particularly in environmental terms, for the development of equestrian tourism and long equestrian traditions, as well as the basic infrastructure for the development of this form of tourism.

An advantage of the Lublin Region is the landscape resulting from varied environmental features (plant assemblages, land relief and lakes) from the lowlands in the northern part (Polesie Lubelskie and Polesie Wołyńskie) with a high number of lakes, through uplands (Lublin Upland, Wołyń Upland and Roztocze) locally with the landscape of loess gullies of the Nałęczów Plateau and West Roztocze in the middle part, to premonatne basins (Sandomierz Basin) in the southern part. Such variation of landscapes permits designing horse trails with varied degrees of difficulty and varied bioclimatic and phytotherapeutic effect of plant assemblages.

A very important aspect influencing the possibility of development of equestrian tourism in the Lublin Region is the already existing infrastructure of three horse trails and 61 equestrian centres. The basis of their offer is horse, sleigh and chaise riding and horse riding courses. The offers of the regional centres include a wide scope of additional services and special, integration and family events. However, the equipment of trails and the accommodation and gastronomic infrastructure are insufficient.

An integral element influencing the possibilities of development of equestrian tourism in the Lublin Region is the necessity of cooperation between equestrian centres and cooperation with local self-governments and societies in order to develop common designs of trails, among others based on subsidies from European Union funds. The issue of accessibility for tourists, as well as the state and type of the infrastructure existing on the trail should be considered. Already at the design stage, opinions followed by permits of relevant institutions, owners, managers, or administrators should be obtained for the development and labelling of trails. A very positive example of such measures if the Polesie Horse Trail, established based on the cooperation of the Equestrian Centre "Żurawiejka" in Bukowa Mała with the Regional Society of Gmina Sawin.

An important aspect closely related to the possibilities of development of equestrian tourism is promotion of the Lublin Region as a region attractive for practising this form of tourism. The promotion should emphasise the health and economic benefits of practising this form of tourism. A good marketing strategy should be developed, supporting the development of equestrian tourism in the region. Moreover, the innovative character of potential tourist products will attract a wider group of customers.

Equestrian tourism should be considered in the strategy of development of tourism in the Lublin Region, as emphasised by B. Sawicki and S. Pietrzak (2009). This largely depends on local and territorial self-governments as well as social organisations. In order to prepare an accurate strategy, diagnostic studies should be conducted at the first stage, considering issues such as: 1) inventory of tourist resources necessary for the development of equestrian tourism; 2) the size and structure of the current and future tourist traffic with consideration of the most important segments of the demand of the tourist market; 3 ) the size and structure of the current and target service base for equestrian tourism. Effective cooperation of equestrian centres and marketing measures can make equestrian tourism in the Lublin Region an accessible and popular, as well as profitable form of tourism.

The current infrastructure and unique environment constitute a large potential for the development of equestrian tourism in the region. The existing infrastructure, specific for the needs of equestrian tourism, however, should be developed and improved. Relevant promotional tools should also be implemented.

\section{Literature}

1. Grzybowski, M. (2005). Chances and perspectives of development of equestrian tourism in Poland. Rocznik Naukowy Wyższej Szkoły Turystyki i Rekreacji w Warszawie 3, 61-63. (in Polish)

2. Adamowicz, M. \& Świtek I. (2009). Equestrian Tourism in the Świętokrzyskie Mountains region. In K. Chmiel (Ed.), The horse in tourism and recreation (pp. 113-148). Biała Podlaska: PSW. (in Polish)

3. Jasiński, N., Prus K. \& Pięta W. (2006). Equestrian tourism on the Kraków-Częstochowa Upland. In D. Dudkiewicz, F. Midura \& E. Wysocka (Eds.), Tourism and recreation as a factor increasing the attractiveness and competitiveness of the region (pp. 427-435). Warszawa: Almamer Wyższa Szkoła Ekonomiczna. (in Polish)

4. Salita, J. (1999). Horse riding as a form of active tourism. In J. Merski \& J. Warecka (Eds.), Active tourism - qualified tourism (pp. 174-177). Warszawa: Almamer Wyższa Szkoła Ekonomiczna. (in Polish)

5. Jarzębowska, M., Kowalczyk A., Kulczyk S., Kurkowska A. \& Lewandowski W. (2010). Qualified tourism (active tourism) in the concept of sustainable tourism. In A. Kowalczyk (Ed.), Sustainable tourism (pp. 255-272). Warszawa: Wydawnictwo Naukowe PWN (in Polish).

6. Merski, J. \& Warecka J. (2009). Equestrian tourism. In J. Merski \& J. Warecka (Eds.), Qualified tourism and active tourism (pp. 97-115). Warszawa: Almamer Wyższa Szkoła Ekonomiczna. (in Polish)

7. Strauß, I. (1996). Hippotherapy. Neurophysiological therapeutic gymnastics on horseback. Kraków: Fundacja na rzecz rehabilitacji konnej dzieci niepełnosprawnych. (in Polish)

8. Bekasiewicz, N. (Ed.) (2008). Can animals cure? Therapies with participation of animals supporting rehabilitation of the disabled. Warszawa: Fundacja Pomocy Osobom Niepełnosprawnym "Przyjaciel". (in Polish)

9. Józefczyk, M. (2010). The most beautiful Horse Trails in Poland. Warszawa: Carta Blanca. (in Polish)

10. Kubacki, S., Cywińska D., Markiewicz J., Tadych M., Mrozik-Gliszczyńska E., Święcicka, N. et al. (2006). Analysis of selected equestrian centers and agrotourist farms in Poland. Prace Komisji Nauk Rolniczych i Biologicznych BTN, B 61, 47-55. (in Polish)

11. Łojek, J. (2001). Changes in the direction of use of horses in the years 1989-1999. Przeglad Hodowlany 4, 18-22. (in Polish)

12. Gedl-Pieprzyca, I. (2009). Equestrian tourism in Beskid Niski. In K. Chmiel (Ed.), The horse in tourism and recreation (pp. 167-179). Biała Podlaska: PSW. (in Polish)

13. Chodkiewicz, K. \& Drabek E. (2009). Organisation of horse routes and animation of equestrian recreation as the elements of promotion of the State Forests. Studia i Materiały Centrum Edukacji Przyrodniczo-Leśnej 4, 292- 298. (in Polish) 
14. Chmiel, K. (2008). Equestrian tourism as a chance for the promotion of eastern Poland. In M. Jalinik (Ed.), Innovations in the development of tourism (pp. 87-92). Białystok: Politechnika Białostocka. (in Polish)

15. Krzemień, M.P. (Ed.) (2002). Montane equestrian tourism. Kraków: Ostoja. (in Polish)

16. Deszczyńska, A. (2007). Żurawiejka from Dzikie Pola. Koń Polski 9, 22-26. (in Polish)

17. Poleski Horse Trail. Tourist-environmental map (2007). Lublin: Kartpol. (in Polish)

18. http://roztocze.org/pl/page/80/konno-po-roztoczu.html. Retrieved April 28, 2011.

19. Sawicki, B. \& Pietrzak S. (2009). The role of the horse in the development of specialised tourism in rural areas of the Lublin Region. In K. Chmiel (Ed.), The horse in tourism and recreation (pp. 9-18). Biała Podlaska: PSW. (in Polish)

20. Herbert, J. (2009). Organisation and management of equestrian tourism events. In K. Chmiel (Ed.), The horse in tourism and recreation (pp. 103-111). Biała Podlaska: PSW. (in Polish)

21. Janiszewska, J. \& Ignor J. (1998). Equestrian recreation as a chance for development of agrotourism. Przegląd Hodowlany 12, 22-23. (in Polish)

22. Błażejczyk, K. (2004). Bioclimatic conditions of tourist recreation in Poland. Warszawa: IG i PZ PAN. (in Polish)

23. Lisowska, J. (2006). Horse riding as an attractive tourist offer. In A. Dąbrowski \& R. Rowiński (Eds.), Strategy of tourism development in Poland for the years 2007-2013. Theoretical assumptions as inspiration for practice (pp. 156-160). Warszawa: AWF. (in Polish)

24. Jakubiuk, M. (2006). Tourist attractiveness of the stud farm in Janów Podlaski. Zeszyty Dydaktyczno-Naukowe WSHGiT 1, 144-158. (in Polish)

25. http:// www.lubelskie.pl. Retrieved April 27, 2011.

26. Active tourism in the Lublin Region, (2004). Lublin: Wyd. Urząd Marszałkowski Województwa Lubelskiego. (in Polish)

27. Wyżnikiewicz-Nawracała, A. (2002). Horse riding in the motor and psychosocial development of the disabled. Gdańsk: AWFiS. (in Polish)

28. Wojciechowski, K.H. (1993). Visual attractiveness of landscape as a component of recreational values. In M. Pietrzak (Ed.), Ecology of landscape in territorial studies on recreational systems (pp. 38-46). Poznań: Wydawnictwo KIBS. (in Polish)

29. Kruczek, Z. \& Sacha S. (1997). Geography of tourist attractions of Poland. Kraków: Proksenia (in Polish)

30. Maruszczak, H. (1972). Lublin-Wołyń uplands. In M. Klimaszewski (Ed.), Geomorphology of Poland 1 (pp. 340-383). Warszawa: PWN. (in Polish)

31. Świeca, A. \& Brzezińska-Wójcik T. (2009). Regional diversity of geosystems of river catchments of central-eastern Poland in view of studies on outflow of solutions. Prace $i$ Studia Geograficzne 41, 205-218. (in Polish)

32. Gardziel, Z. \& Nowak J. (1996). Polygenesis of the relief of the middle part of Polesie Lubelskie based on the example of the vicinity of Sosnowica. Acta Geographica Lodziensia 71, 43-53. (in Polish)

33. Harasimiuk, M. \& Wojtanowicz J. (1998). Geological structure and land relief of the area of the Łęczna-Włodawa Lakeland. In M. Harasimiuk, Z. Michalczyk \& M. Turczyński (Eds.), Łęczna-Włodawa Lakes. Environmental Monograph (pp. 41-53). Lublin: UMCS. (in Polish)
34. Michalczyk, Z. (1996). Water relations of the Łęczna-Włodawa Lakeland. In M. Harasimiuk, Z. Michalczyk \& M. Turczyński (Eds.), Łęczna-Włodawa lakes. Environmental Monograph (pp. 55-71). Lublin: UMCS. (in Polish)

35. Kaszewski, B. (2008). Climate. In S. Uziak \& R. Turski (Eds.), Natural Environment of the Lublin Region (pp. 75-111). Lublin: Lubelskie Towarzystwo Naukowe. (in Polish)

36. Fijałkowski, D. \& Izdebski K. (2008). Vegetation. In S. Uziak \& R. Turski (Eds.), Natural Environment of the Lublin Region (pp. 317-419). Lublin: Lubelskie Towarzystwo Naukowe. (in Polish)

37. Krzymowska-Kostrowicka, A. (1999). Geoecology of tourism and recreation. Warszawa: Wydawnictwo Naukowe PWN. (in Polish)

38. Kondracki, J. \& Richling A. (1994) Physicogeographical regions. In Atlas of the Republic of Poland. Warszawa: Główny Geodeta Kraju. (in Polish)

39. Michalczyk, Z. \& Wilgat T. (2008). Waters. In S. Uziak \& R. Turski (Eds.), Natural environment of the Lublin Region (pp.113-210). Lublin: Lubelskie Towarzystwo Naukowe (in Polish)

40. Wojtanowicz, J. (1992). Physicogeographical division of the Sandomierz Basin. Annales UMCS B, 44/45(1989/1990), 3, 67-93. (in Polish)

41. Buraczyński, J. (1993). Development of aeolian processes of the Vistula River level in Roztocze and Sandomierz Basin. Lublin: Wyd. UMCS. (in Polish)

42. Wyrzykowski, J. (1984). Optimal periods of the touristic use of the recreational values of the natural environment of Poland. Acta Universitatis Wratislaviensis B, 656, 5, 123-134. (in Polish)

43. Przybyłowska, I. (1978). Free-form interview with a standardised list of required information and possibility of its application in sociological studies. Przeglad Socjologiczny XXX, 53-68. (in Polish)

44. http://www.stadniny.pl. Retrieved April 28, 2011.

45. http://www.ar.lublin.pl/oferta/. Retrieved March 25, 2011.

46. http://aktywni.pl/aktualnosci/hubertus-czyli-swietojezdzcow/. Retrieved February 12, 2011.

47. http://www.galopuje.pl. Retrieved April 28, 2011.

48. http://www.zamosc.pttk.pl. Retrieved August 29, 2011.

49. Kuśmierczyk, P. \& Grudzień A. (2009). Economic aspects of the tourist product involving the use of horses in the opinion of owners of agrotourist farms in the Lublin poviat. In $\mathrm{K}$. Chmiel (Ed.), The horse in tourism and recreation (pp. 103111). Biała Podlaska: PSW. (in Polish)

50. Gosik, B. \& Piech, M. (2012). The Łódź Horse Trail as an example of a branded tourist product of the Eódź Region. Zeszyty Naukowe Uniw. Szczecińskiego, Ekonomiczne Problemy Usług 86, 67-81. (in Polish)

Submitted: November 23, 2012

Accepted: December 21, 2012 